\title{
Erythrocyte Formation Rate in Wistar Anemia Induced 2,4-Dinitrophenylhydrazine through Intake Maize Biofortified Iron
}

Jumadi Muhammadong ${ }^{1 *}$, Saifuddin Sirajuddin ${ }^{2}$, M. Natsir Djide ${ }^{3}$, Anwar Mallongi ${ }^{4}$

${ }^{1}$ Department of Public Health, Hasanuddin University, Makassar City, South Sulawesi, Indonesia; ${ }^{2}$ Department of Nutrition, Faculty of Public Health, Hasanuddin University, Makassar City, South Sulawesi, Indonesia; ${ }^{3}$ Departments of Pharmacology, Hasanuddin University, Makassar City, South Sulawesi, Indonesia; ${ }^{4}$ Department of Environmental Health, Faculty of Public Health, Hasanuddin University, Makassar City, South Sulawesi, Indonesia

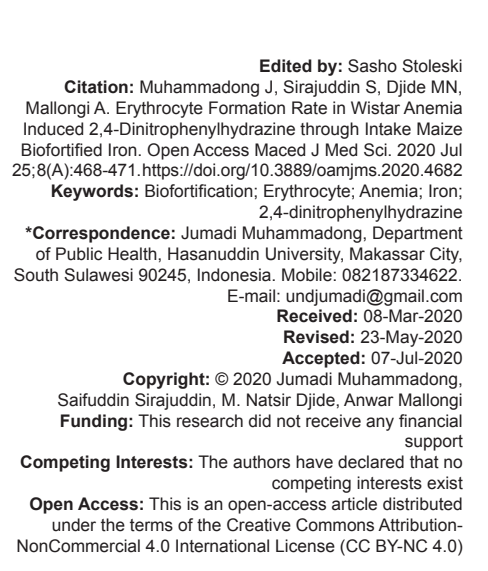

\section{Abstract}

BACKGROUND: Biofortification through Pseudomonas putida IFO 14796 intervention has succeeded to improve iron content in maize grain up to $18.79 \%$.

AIM: This study was carried out to assess the effect intake of maize biofortified iron (MBI) on the red blood cell (RBC) formation rate in Wistar rat anemia induced 2,4 dinitrophenylhydrazine.

METHODS: Randomized complete design was carried out to assess the effect of MBI on the erythrocyte level with four levels of $\mathrm{MBI}$ treatment (R1=10\%; R2=12\%; $\mathrm{R} 3=14 \%$, and $\mathrm{R} 4=16 \%$ of rat body weight $[\mathrm{BW}]$ ) and one of contro (Ro=10\% maize non-biofortified iron), and five replications, respectively. Erythrocyte level was measured using the Counting Neubauer Chamber Method after Wistar anemia induced 2,4-dinitrophenylhydrazine (DPNH) after intake $\mathrm{MBI}$ for 7 days. Data were analyzed by ANOVA and Fisher's least significant difference.

RESULTS: There was an influence intake of MBI level on the improving rate the erythrocyte formation in Wistar anemia $(p<0.05)$. Treatment $R 1$ improved to $0.058 \pm 0.034 \%$ significantly different with $R 0(0.006 \pm 0.017 \%)$, but nonsignificantly with $R 2$ and $R 4$ at $p<0.05$. Linear regression showed the equation, $y=-0.002 x+0.07 ; R^{2}=0.69$.

CONCLUSION: Intake MBI more than $10 \%$ BW negatively effect to RBC formation rate of Wistar rat's anemia.

\section{Introduction}

Malnutrition and iron-deficiency anemia the main issue in various countries in the world and become a factor to increase the mortality rate. The main type of malnutrition from micronutrient was an iron, Zn, and Vitamin A deficiency [1]. Iron deficiency in the body can be caused by low iron, and Vitamin $C$ intake, low iron absorption from foods high in phytate or phenol compounds, blood loss, parasitic infections, even manifestations of chronic kidney diseases, malignancies, and autoimmune disorders [2], [3], [4], [5]. Deficiency iron supply from food can decrease in hemoglobin, hematocrit, and erythrocytes formation [6], [7].

Strategies to reduce the burden of the iron deficiency can be done by modification food, provide $\mathrm{Fe}$ supplement or fortification, and food biofortified iron. While biofortification can be done through transgenic, conventional plant breeding, and agronomic interventions through micronutrient fertilizer application [8]. Biofortification through Pseudomonas putida IFO 14796 intervention has succeeded to improve iron content in maize grain up to $18.79 \%$ [9].

Consumption of pearl millet biofortified iron (Pennisetum glaucum) from transgenic has been increased absorption, and effectively overcome the iron deficiency in people [10]. However, some arguments show that food products from transgenics have serious effects on the genetic changes in consumer. In addition, iron accumulation in the brain plays a central role for inducing oxidative stress in neurodegeneration [6], [11]. This study was carried out to assess the effect intake of maize biofortified iron (MBI) contained $10.117 \mathrm{mg} / \mathrm{kg}$ on erythrocyte formation in Wistar rat anemia.

\section{Materials and Methods}

\section{Location and time}

The experiment was undertaken for 21 days from December 17, 2019, to January 05, 2020, in 
the center for an integrated laboratory of Dayanu Ikhsanuddin University, Baubau City, Southeast Sulawesi-Indonesia.

\section{Experimental materials}

Female Wistar was accessed from Bandung, Indonesia (Certificate Veterine: No. 524.3/3873-Dispangtan/2019). Female Wistar rats anemia resulted from induced by injection $40 \mathrm{mg} / \mathrm{kg}$ 2,4 dinitrophenylhydrazine for 4-7 days. MBI contained $10.117 \mathrm{mg} / \mathrm{kg}$ was produced from the previous project through $P$. putida IFO 14796 intervention.

\section{Design experiment}

The research was carried out with the randomized complete design, consisting of four treatment groups and one control group. The treatment group contained experiment units R1 (10\%), R2 (12\%), R3 (14\%), R4 (16\%), and R0 (10\%) of body weight (BW). $\mathrm{MBI}$ was an independent variable, and erythrocyte level for the dependent variable. The sample size was 25 female Wistar anemia (Rattus novergicus) randomly placed into five groups. Each group consisted of five animals that were placed separately in a $30 \mathrm{~cm} \times 25 \mathrm{~cm}$ $\times 30 \mathrm{~cm}$ cage. The treatment group of Wistar anemia was supplied food from MBI 3 times a day as well as a control group by maize non-biofortified iron, and water drinking by ad libitum [12]. In addition, Wistar anemia was treated well in a room with good ventilation, normal sun exposure through the window, temperature $27-30^{\circ} \mathrm{C}$, and low humidity. Blood was taken from the lateral vein of rat's tail based on standard operational procedure (SOP) Intravenous Injection in the Rat [13] for measuring the total erythrocyte of using Counting Neubauer Chamber Method [14].

\section{Data analysis}

The effect of intake of the MBI for the erythrocyte formation rate in Wistar anemia was analyzed using statistical ANOVA one-way and Fisher's least significant difference (LSD) at $p<0.05$.

\section{Results}

The mean erythrocyte of Wistar rat anemia was $5.34-6.55 \times 10^{6} \mu \mathrm{L}^{-1}$ in range, whereas the number of erythrocytes has increased to be $5.74-8.74 \times 10^{6} \mu \mathrm{L}^{-1}$ in range after intake $\mathrm{MBI}$ for 7 consecutive days. The highest erythrocyte formation rate occurred in the treatment R1 $(0.058 \pm 0.034)$ and the lowest in the R3 $(-0.008 \pm 0.011 \%)$ (Table 1).
Table 1: Average of erythrocyte formation rate of Wistar rats after intake maize biofortified iron $\left(\% \mathrm{~d}^{-1}\right)$

\begin{tabular}{|c|c|c|c|}
\hline \multirow[t]{2}{*}{ Treatment } & \multicolumn{2}{|c|}{ Number of erythrocyte } & \multirow{2}{*}{$\begin{array}{l}\text { Means rate } \pm \mathrm{SD} \\
\left(\% \mathrm{~d}^{-1}\right)\end{array}$} \\
\hline & $\left(\times 10^{6} / \mu \mathrm{L}\right)$ & $\left(\times 10^{6} / \mu \mathrm{L}\right)$ & \\
\hline R0 & $5.50 \pm 0.44$ & $5.78 \pm 0.74$ & $0.006 \pm 0.017^{\circ}$ \\
\hline R1 & $5.34 \pm 0.31$ & $8.74 \pm 2.72$ & $0.058 \pm 0.034^{\mathrm{a}}$ \\
\hline R2 & $5.51 \pm 0.39$ & $6.65 \pm 0.78$ & $0.030 \pm 0.022^{\mathrm{a}}$ \\
\hline R3 & $5.41 \pm 0.44$ & $5.03 \pm 0.16$ & $-0.008 \pm 0.011^{b}$ \\
\hline R4 & $6.55 \pm 1.42$ & $5.74 \pm 0.79$ & $0.010 \pm 0.032^{\mathrm{a}}$ \\
\hline
\end{tabular}

The analysis of variance showed a significant effect of $\mathrm{MBI}$ intake on the erythrocytes formation rate in Wistar rats anemia $(p<0.05)$. Likewise, with Fisher's LSD test showed a different means of erythrocyte formation rate in R1, R2, R4, against R0 (control) at $p<0.05$ (Table 1). The erythrocyte formation rate in Wistar rats anemia tends to decrease with increase the level of $\mathrm{MBI}$ intake (\%), while based on the linear regression analysis obtained the equation: $Y=-0.018 x+0.067, \quad R^{2}=0.688$ (Figure 1). Thus, MBI intake was negatively correlated to the erythrocyte formation rate in Wistar rats anemia. The formation erythrocyte of red blood cells tends to decrease with increasing $\mathrm{MBI}$ intake more the $10 \%$.

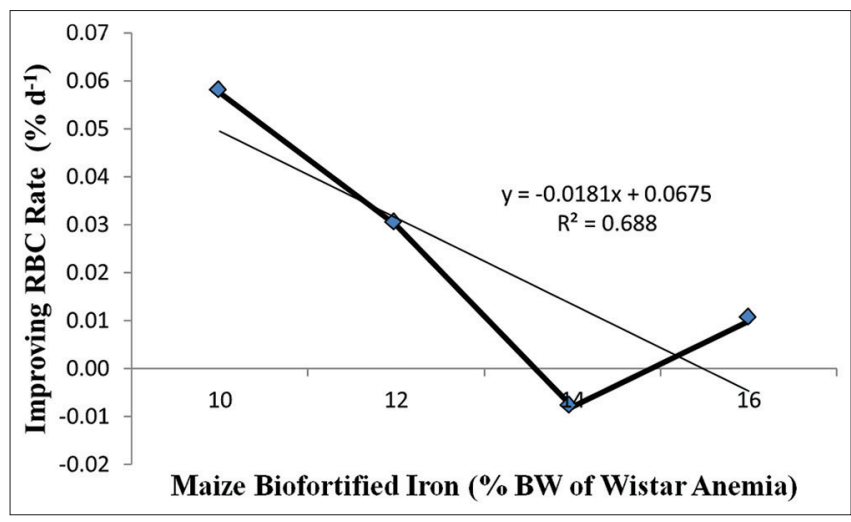

Figure 1: Erythrocyte formation rate with intake maize biofortified iron level

\section{Discussion}

The erythrocyte formation tends to decrease with increased intake of MBI. Erythrocyte formation rate was a variety from $(-0.008 \pm 0.011 \%)$ to $(0.058 \pm 0.034 \%)$ per day in range. According to Monette et al. [15], the formation of erythrocytes in Wistar rats has been undertaken up to $6.5 \mathrm{~h}$. However, increasing erythropoiesis stimulation in the lymph up to 5-6 times and 2-3 in the bone marrow if there was acute bleeding or hypoxia. During bleeding, lymphatics increase erythropoiesis from $10 \%$ to $40 \%$ in normal conditions [16]. However, erythropoiesis can only take place perfectly if nutritional supply enough for the production of globins and heme such as amino acids, iron, Vitamins B12, B6, and folic acids (component B2), nickel (Ni) and cobalt (Co), and erythropoietin hormone [17]. 
Maize grain contains protein stored in the lumen of the endoplasmic reticulum, rich in beta, and gammazein [18], and contains about 1756 kind of proteins [19], leucine, lysine, tryptophan, methionine, isoleucine, valine, phenylalanine, glutamic acid, serine, alanine, tyrosine, and proline [20], [21], while the fat content of maize grain was $3.21-7.71 \%$ in the range [22]. The low erythrocyte formation in Wistar anemia with increase intake $\mathrm{MBI}$ level may be related to high inhibitor iron absorption in the maize grain.

Phytate, polyphenols, calcium, ascorbic acid, and tissue were able to inhibit the absorption of iron [23]. Maize grain contained high phytate compounds in fresh corn up to $1.71 \mathrm{~g} / \mathrm{kg}$ and dry corn (7.15-7.60 g/kg). However, heating will be able to reduce the levels of phytate acid in fresh corn by 18.1 $46.7 \%$ and dry corn (11-5-52.6\%). This study treated dried maize grain with soaked in water for $24 \mathrm{~h}$ and then heated in the presto cooker at $100^{\circ} \mathrm{C}$ for $10 \mathrm{~min}$. This was intended to help reduce phytic acid levels in dried maize grain. However, the erythrocyte formation rate tends to decrease with $\mathrm{MBI}$ level. The weakness of this study is the absence of observations of Vitamin $B$, folic acid, and others important factor supporting the erythrocyte formation.

\section{Conclusion}

The maximum level of $\mathrm{MBI}$ for erythrocyte formation in Wistar rats anemia was $10 \%$ of $\mathrm{BW}$. Forward research is important to confirm the human equivalence iron dose (HEID) from MBI for children and adult in anemia.

\section{Acknowledgment}

The author would like to acknowledge to all of the staff of the Biology Department of Institute Technology of Bandung, Indonesia, and Rector of Dayanu Ikhsanuddin University for the permission undertaken the study on the Department of Public Health, Hasanuddin University, Makassar City, South Sulawesi, Indonesia.

\section{References}

1. Dipti SS, Bergman C, Indrasari SD, Herath T, Hall R, Lee H, et al. The potential of rice to offer solutions for malnutrition and chronic diseases. Rice (N Y). 2012;5(1):16. https://doi. org/10.1186/1939-8433-5-16

PMid:24279770

2. Trabelsi S, Oueslati J, Aouinet A, Khaled S. Anemia caused by parasites. Tunis Med. 2014;92(6):361-7.

PMid:25741835

3. Sobani Z, Shakoor S, Malik F, Malik E, Beg MA. Gastrointestina helminthiasis presenting with acute diarrhea and constipation: Report of two cases with a second pathology. Trop Biomed. 2010;27(2):348-50.

PMid:20962736

4. World Health Organization. Guidelines on Food Fortification with Micronutrients: World Health Organization and Food and Agricultural Organization of the United Nations. Geneva: World Health Organization; 2006.

5. Gebreegziabiher G, Etana B, Niggusie D. Determinants of anemia among children aged 6-59 months living in kilte awulaelo woreda, Northern Ethiopia. Anemia. 2014;2014:245870. https:// doi.org/10.1155/2014/245870

6. Wick M, PinggeraW, Lehmann P. ClinicalAspects and Laboratoryiron Metabolism, Anemias. $6^{\text {th }}$ ed. Austria: Thomson Press (India) Ltd.; 2011. https://doi.org/10.1007/978-3-7091-0087-5

7. World Health Organization. Assessing the Iron Status of Population. $2^{\text {nd }}$ ed. Geneva, Switzerland: Department of Nutrition for Health and Development; 2007.

8. Yin X, Yuan L. Phytoremediation and Biofortification. London: Springer Dordrecht Heidelberg; 2012.

9. Muhammadong J, Sirajuddin S, Djide MN, Mallongi A. Root inoculation with pseudomonas putida IFO 14796 for improving iron contents in maize grain. J Food Resour Sci. 2019;8(1):1-5. https://doi.org/10.3923/jfrs.2019.1.5

10. Cercamondi Cl, Egli IM, Mitchikpe E, Tossou F, Zeder C Hounhouigan JD, et al. Total iron absorption by young women from iron-biofortified pearl millet composite meals is double that from regular millet meals but less than that from post-harvest iron-fortified millet meals. J Nutr. 2013;143(9):1376-82. https:// doi.org/10.3945/jn.113.176826 PMid:23884388

11. Chen JH, Singh N, Tay H, Walczyk T. Imbalance of iron influx and efflux causes brain iron accumulation over time in the healthy adult rat. Metallomics. 2014;6(8):1417-26. https://doi. org/10.1039/c4mt00054d

PMid:24752826

12. Toma I, Victory NC, Kabir A. The effect of aqueous leaf extract of fluted pumpkin on some hematological parameters and liver enzymes in 2,4-dinitrophenylhydrazine-induced anemic rats. Afr J Biochem Res. 2015;9(7):95-8. https://doi.org/10.5897/ ajbr2014.0771

13. Andrews K. Intraperitoneal(IP) Injection in Rats and Mice (SOP). Available from: https://www.research.vt.edu/university-vet. [Last accessed on 2019 Dec 20].

14. Ologundudu A, Ologundudu AO, Ololade A, Obi FO. Effect of Hibiscus sabdariffa anthocyanins on 2, 4-dinitrophenylhydrazineinduced hematotoxicity in rabbits. Afr $\mathrm{J}$ Biochem Res. 2009;3(4):140-4.

15. Monette F, LoBue J, Gordon A, Alexander PJ, Chan P. Erythropoiesis in the rat: Differential rates of DNA synthesis and cell proliferation. Science. 1968;162(3858):1132-4. https://doi. org/10.1126/science.162.3858.1132 PMid:5698854

16. Pantel K, Loeffler M, Bungart B, Wichmann H. A mathematical model of erythropoiesis in mice and rats. Part 4: Differences between bone marrow and spleen. Cell Tissue Kinet. 1990;23(4):283-97. https://doi.org/10.1111/j.1365-2184.1990. tb01125.x

PMid:2202515 
17. Palis J, Segel G. Developmental biology of erythropoiesis. Blood Rev. 1998;12(2):106-14.

\section{PMid:9661799}

18. Lending CR, Larkins BA. Changes in the zein composition of protein bodies during maize endosperm development. Plant Cell. 1989;1(10):1011-23. https://doi.org/10.2307/3869002 PMid:2562552

19. Wang G, Wang G, Wang J, Du Y, Yao D, Shuai B, et al. Comprehensive proteomic analysis of developing protein bodies in maize (Zea mays) endosperm provides novel insights into its biogenesis. J Exp Bot. 2016;67(22):6323-35. https://doi. org/10.1093/jxb/erw396 PMid:27789589

20. Li Y, Wang Y, Wei M, Li X, Fu J. QTL identification of grain protein concentration and its genetic correlation with starch concentration and grain weight using two populations in maize (Zea mays L.). J Genet. 2009;88(1):61-7. https://doi. org/10.1007/s12041-009-0008-z

PMid: 19417545

21. Josiane SA, Bienvenu AV, Wilfried PS, Adolphe A, Djima A, Joachin G, et al. Nutritional properties assessment of endogenous and improved varieties of maize (Zea mays L.) grown in Southern Benin. Pak J Biol Sci. 2017;20(6):267-77. https://doi.org/10.3923/pjbs.2017.267.277

PMid:29023051

22. Ikram U, Muhammad A, Arifa F. Chemical and nutritional properties of some maize (Zea mays L) varieties grown in NWPF, Pakistan. Pak J Nutr. 2010;9(11):1113-7. https://doi. org/10.3923/pjn.2010.1113.1117

23. Hurrell R, Egli I. Iron bioavailability and dietary reference values. Am J Clin Nutr. 2010;91(5):1461S-7.

PMid:20200263 